La Revista Panamericana de Salud Pública/Pan American Journal of Public Health se complace en publicar cartas de los lectores dirigidas a estimular el diálogo sobre los diversos aspectos de la salud pública en las Americas, así como a esclarecer, discutir o comentar de manera constructiva las ideas expuestas en ia revista. Las cartas deben estar firmadas por el autor y especificar su afiliación profesional y dirección postal. Cuando se trate de comentarios sobre un artículo que requieren contestación del autor, se procurará conseguir esa respuesta con el fin de publicar ambas cartas. La Redacción se reserva el derecho de editar las cartas recibidas y resumirlas para mayor claridad.

The Revista Panamericana de Salud Pública/Pan American Journal of Public Health publishes letters from readers for the purpose of stimulating dialogue on various aspects of public health in the Americas and of constructively clarifying, discussing, and critiquing the ideas expressed throughout its pages. Letters should be signed by the author and include his or her professional affiliation and mailing address. If a commentary on a given article requires a reply from the author, an effort will be. made to obtain the reply and to publish both letters. The editorial team reserves the right to edit all letters received and to condense them so as to improve their clarity.

\section{COLLECTION, PRESERVATION, AND TRANSPORT OF FIELD SPECIMENS FOR MOLECULAR INVESTIGATIONS}

In the developing countries of Latin America and other regions of the world, there has been a phenomenal rise in molecular biology studies used to diagnose communicable and noncommunicable disorders. With clinical materials, polymerase chain reaction (PCR) is useful in diagnosing Leishmania in American cutaneous leishmaniasis (1) and in diagnosing dengue virus (2). Undoubtedly, it would be feasible in the future to depend on PCR and/or other molecular biology studies for a rapid and specific diagnosis of bacteria, parasites, or viruses in different specimens collected from the field.

With simpler, conventional tests in developing countries, there are many obstacles to ideal approaches to collecting pathological materials and transporting them to the laboratory. Researchers and national health care organizations should better address similar issues relating to molecular investigations. Doing that would ensure ideal field collection of specimens and storage of them before molecular studies are performed.
Of the nucleic acids, DNA is relatively stable, and RNA is fairly labile. The RNA-targeted sequences in pathological specimens are preserved through removal of any RNases released in such specimens (3). It is also possible to stabilize RNA in specimens by adding such commercial products as RNAlater ${ }^{\mathrm{TM}}$ (Ambion, Inc., Austin, Texas, United States of America). Furthermore, during the pre-analytic phase of short tandem repeat DNA typing analysis, the addition of GenoFix ${ }^{\mathrm{TM}}$ (DNA Genotek Inc., Ottawa, Ontario, Canada), an alcohol-based tissue fixative, enabled preservation of DNA in biopsy tissue even at room temperature for up to one year and seven months, and at $-20{ }^{\circ} \mathrm{C}$ for up to three and a half years (4).

The amplified genetic material in any PCR, including a reverse transcriptase-polymerase chain reaction (RT-PCR), is often characterized by ethidium bromide staining of such materials following gel electrophoresis. That procedure may not be infallible in amplified materials that have been subjected to rough handling in the pre-analytic phase. During the storage of clinical specimens containing hepatitis B virus DNA at $4{ }^{\circ} \mathrm{C}$ for 16 months, there was $0.5-1.0 \log _{10}$ loss in the herpesvirus DNA, as evidenced by a quantitative real-time PCR (5). 
Instructions for ideal collection, storage, and transportation of clinical, forensic, and field specimens for molecular investigations would interest innumerable disciplines. The addition of preservatives of nucleic acids would also eliminate any possible erroneous results for field samples for PCR, including RT-PCR.
Subhash C. Arya

Research Physician

Centre for Logistical Research and Innovation

M-122 Greater Kailash-Part 2

New Delhi-110048, India

E-mail: subhashji@hotmail.com

\section{References}

1. Marques MJ, Volpini AC, Genaro O, Mayrink W, Romanha AJ. Simple form of clinical preservation and Leishmania DNA extraction from human lesions for diagnosis of American cutaneous leishmaniasis via polymerase chain reaction. Am J Trop Med Hyg 2001:65:902-906.

2. De Paula SO, Lima DM, Da Fonseca BA. Detection and identification of dengue-1 virus in clinical samples by a nested PCR followed by restriction enzyme digestion of amplicons. J Med Virol 2002;66:529-534.

3. Kiechle FL, Zhang X, Malinski T. The molecular pathology laboratory of the 21st century. Ann Clin Lab Sci 1999;29(1):59-77.

4. Fregeau CJ, Vanstone H, Borys S, McLean D, Maroun JA, Birnboin HC, et al. AmpFISTR Profiler Plus and AmpFISTR COfiler analysis of tissues stored in GenoFix, a new tissue preservation solution for mass disaster DNA identification. J Forensic Sci 2001;46(5):1180-1190.

5. Jerome KR, Huang M-L, Wald A, Selke S, Corey L. Quantitative stability of DNA after extended storage of clinical specimens as determined by real-time PCR. J Clin Microbiol 2002;40(7):26092611.

\section{Revista/Journal Article Receives National Award in Cuba}

An article published in the October 2001 issue of the Revista Panamericana de Salud Pública/Pan American Journal of Public Health has won a major national health award in Cuba. The award, granted in September 2002, was given to recognize an article carried in a scientific journal, one of the categories in the National Competition for the Annual Health Award (Concurso Nacional del Premio Anual de la Sa(ud). The annual competition is organized by Cuba's National Council of Scientific Societies (Consejo Nacional de Sociedades Científicas) and has categories that include: scientific theory, basic research, applied research, introducing technologies, technology assessment, scientific article, and book. To be considered at the national level, works must first be chosen at the provincial level. At the national level, judges assess the nominees and may or may not choose to recognize works in each of the categories. The works that are selected receive either an award or an honorable mention.

The Revista/Journal article that won the award is entitled "Prevalence estimates for hypertension in Latin America and the Caribbean: are they useful for surveillance?" One of the co-authors, Luis Carlos Silva, is with the Instituto Superior de Ciencias Médicas de La Habana, Cuba. The other co-authors are affiliated with the Pan American Health Organization. That article was a companion piece to an article by the same co-authors that was carried in the September 2001 issue entitled "A tool for assessing the usefulness of prevalence studies done for surveillance purposes: the example of hypertension." The October 2001 issue also carried an editorial commenting on the two articles. 